\title{
Various Chemical Properties and Advantages of Green Cement Manufacturing
}

\author{
Dr. Antino Marelino \\ ARCET Malaysia \\ antinomy_research@live.com
}

\section{Abstract}

It is an idea of using environmentally friendly materials in concrete, to make the system progressively supportable. These are referred to as the useless energy in their production and produces less $\mathrm{CO} 2$ which causes Global Warming. Concrete wastes like slag, power plant wastes, recycled concrete, mining and quarrying wastes, waste glass, burnt clay, sawdust, combustor ash and foundry sand.

Keywords: Recycled concrete Lime, clay etc.

\section{INTRODUCTION}

Green concrete is a eco-friendly because it is made by the concrete waste so it is also called eco-friendly concrete. Green cement is all the time and furthermore modest to create, in light of the fact that for instance, waste items are utilized as a partial substitute for concrete, charges for the removal of waste are avoided, and robustness is greater. Its making reduces cement intake, and its major raw materials include discarded industrial wastes like blast furnace slag and fly ash. Carbon dioxide emitted throughout the built-up process is considerably reduced. The cement has come up with certain formulas where Saltwater or even Wastewater can be effectively used at places where fresh water is not in abundance. Green cement will offer low cost and quality benefits in future. 


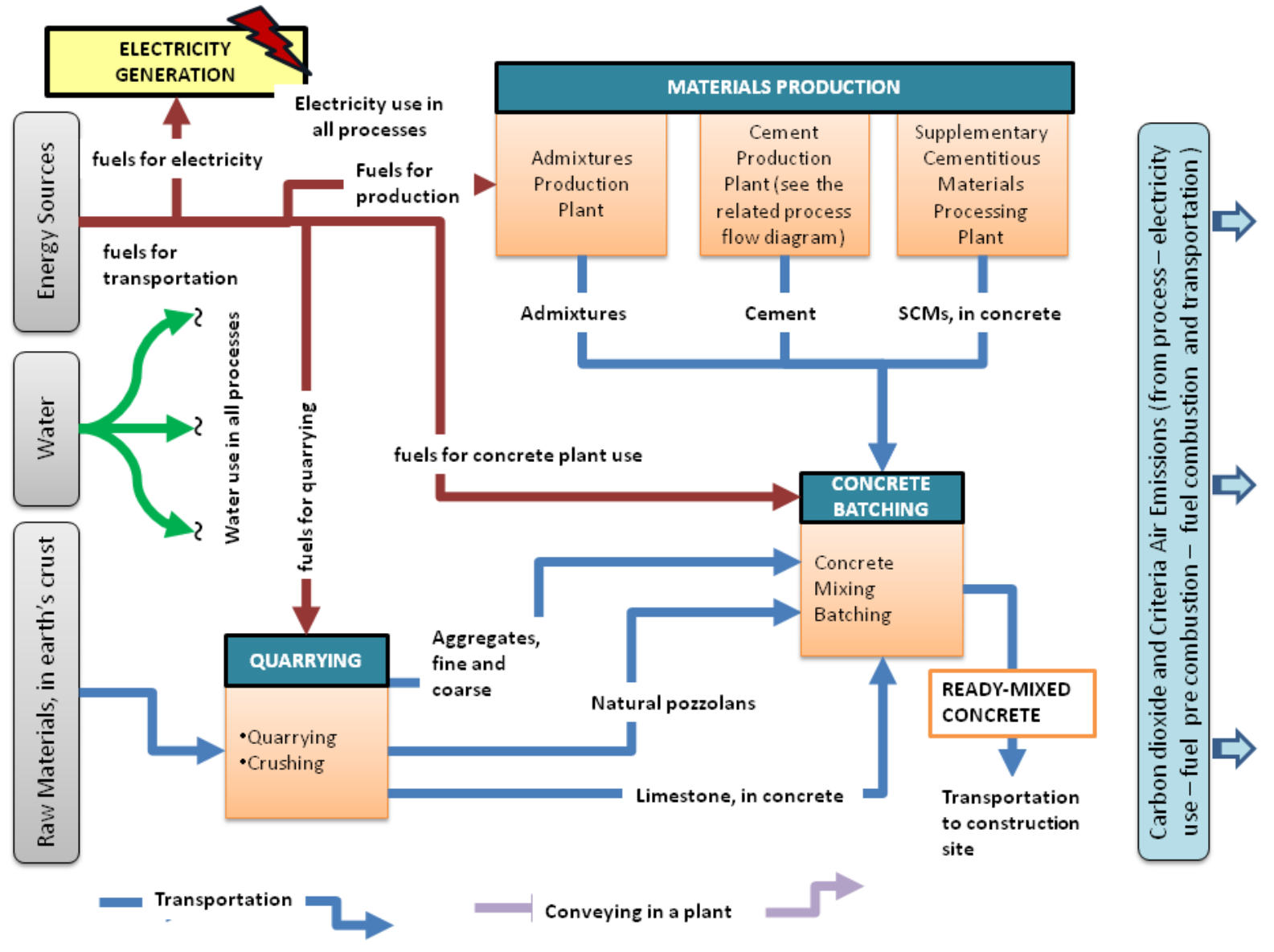

Fig 1: green cement manufacture process

Table 1

Physical Properties of Quarry Rock Dust

\begin{tabular}{|l|c|}
\hline \multicolumn{1}{|c|}{ Property } & $\begin{array}{c}\text { Quarry } \\
\text { Rock Dust }\end{array}$ \\
\hline Specific gravity & $2.54-2.60$ \\
\hline Bulk relative density $(\mathrm{kg} / \mathrm{m} 3)$ & $1720-1810$ \\
\hline Absorption (\%) & $1.20-1.50$ \\
\hline Moisture content $(\%)$ & Nil \\
\hline Fine particles less than $0.075 \mathrm{~mm} \mathrm{( \% )}$ & $12-15$ \\
\hline Sieve analysis & Zone II \\
\hline
\end{tabular}


Table 2

Chemical Properties of Fly Ash

\begin{tabular}{|c|l|c|c|}
\hline $\begin{array}{c}\text { Sl. } \\
\text { No. }\end{array}$ & \multicolumn{1}{|c|}{ Test Conducted } & $\begin{array}{c}\text { Observed } \\
\text { Values (\%) }\end{array}$ & $\begin{array}{c}\text { Requirement as } \\
\text { per IS:1320-1981 }\end{array}$ \\
\hline 1 & Loss of Ignition & 2.32 & $5.0($ max) \\
\hline 2 & Silica as $\mathrm{SiO}_{2}$ & 42.04 & $\begin{array}{c}\mathrm{SiO}_{2}+\mathrm{Fe}_{2} \mathrm{O}_{3}+ \\
\mathrm{Al}_{2} \mathrm{O}_{3}=70\end{array}$ \\
\hline 3 & Iron as $\mathrm{Fe}_{2} \mathrm{O}_{3}$ & 4.40 & - \\
\hline 4 & Alumina as $\mathrm{Al}_{2} \mathrm{O}_{3}$ & 33.60 & - \\
\hline 5 & Calcium as $\mathrm{CaO}$ & 12.73 & - \\
\hline 6 & Magnesium as $\mathrm{MgO}$ & 0.00 & 5.0 \\
\hline 7 & Sulphate as $\mathrm{SO}_{3}$ & 0.40 & 3.0 \\
\hline 8 & Chloride & - & \\
\hline 9 & Lime Reactivity & $4 \mathrm{~N} / \mathrm{mm}^{2}$ & 4.5 \\
\hline
\end{tabular}

Highly Resistant to Water, Acids, Corrosion, Sulfates

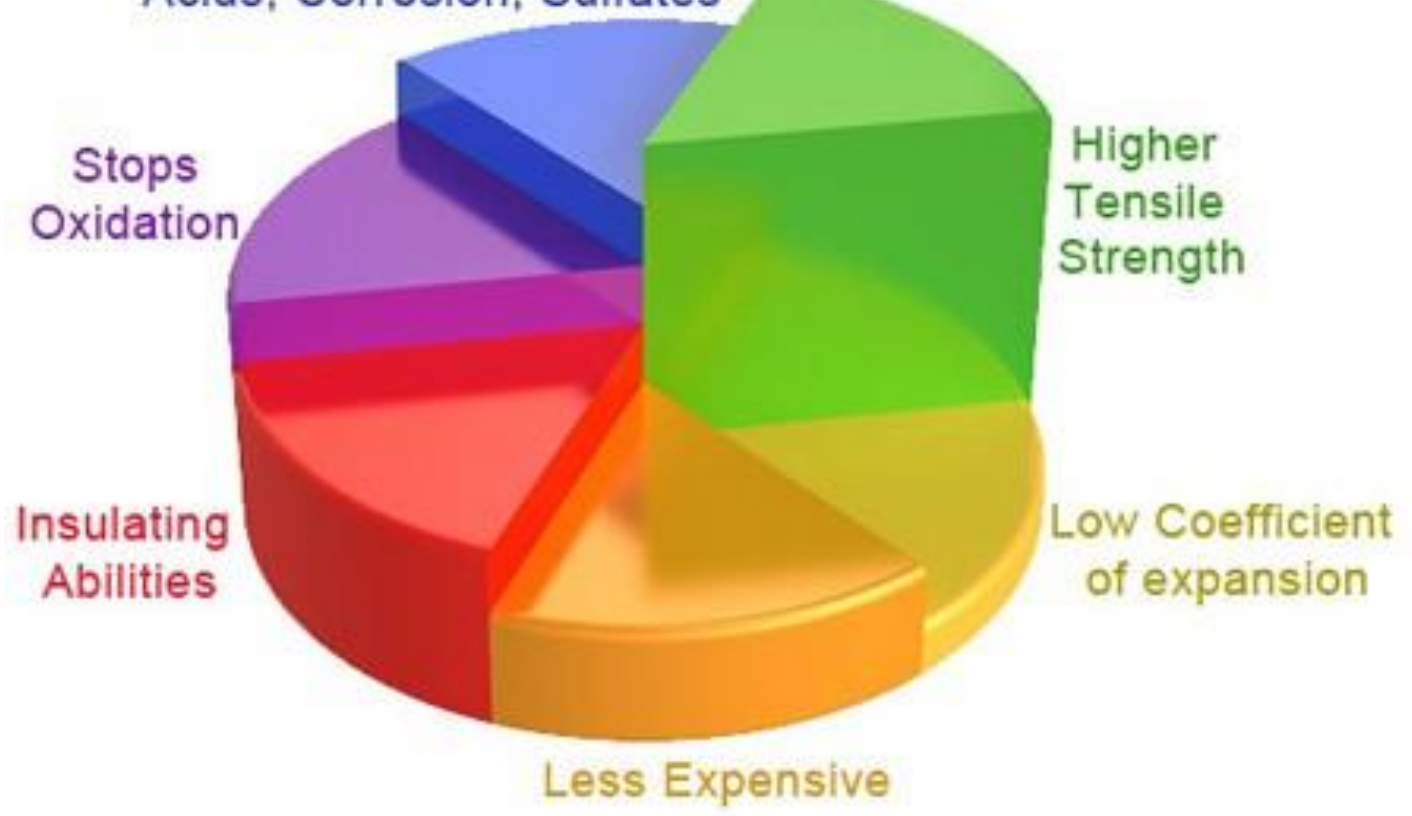

Fig2: benefits of green cement 


\section{ADVANTAGES OF GREEN CEMENT}

\begin{tabular}{|c|c|c|}
\hline S.no. & concept & Advantages \\
\hline 1. & Workability & $\begin{array}{l}\text { Green concrete having better workability than } \\
\text { conventional concrete. }\end{array}$ \\
\hline 2. & $\mathrm{CO}_{2}$ Emission & $\begin{array}{l}\text { Reduction of the concrete industry's CO2-emmision by } \\
30 \% \text {. }\end{array}$ \\
\hline 3. & Waste Product & $\begin{array}{l}\text { Increased concrete industry's use of waste products by } \\
20 \% \text {. }\end{array}$ \\
\hline 4. & $\begin{array}{l}\text { environmental } \\
\text { pollution }\end{array}$ & $\begin{array}{l}\text { NO environmental pollution and sustainable } \\
\text { development. }\end{array}$ \\
\hline 5. & maintenance & Green concrete requires low maintenance and repairs. \\
\hline 6. & resistant & Good thermal resistant and fire resistant. \\
\hline 7. & $\begin{array}{l}\text { Compressive strength } \\
\text { behavior }\end{array}$ & $\begin{array}{l}\text { Compressive strength behavior of concrete with water } \\
\text { cement ratio is similar to conventional concrete. }\end{array}$ \\
\hline 8. & $\begin{array}{l}\text { strength, durability, } \\
\text { and elasticity }\end{array}$ & $\begin{array}{l}\text { The product has higher strength, durability, and elasticity } \\
\text { which makes the concrete everlasting and low } \\
\text { maintenance. }\end{array}$ \\
\hline 9. & less energy & $\begin{array}{l}\text { Green Cement requires significantly less energy to } \\
\text { produce, thus leaving a substantially smaller carbon } \\
\text { footprint. }\end{array}$ \\
\hline 10. & cost-effective & $\begin{array}{l}\text { The manufacturing process of Green cement does not } \\
\text { involve the use of large energy-intensive kilns which } \\
\text { makes it cost-effective. }\end{array}$ \\
\hline
\end{tabular}

\section{GLOBAL GREEN CEMENT MARKET SHARE, BY APPLICATION 2025}

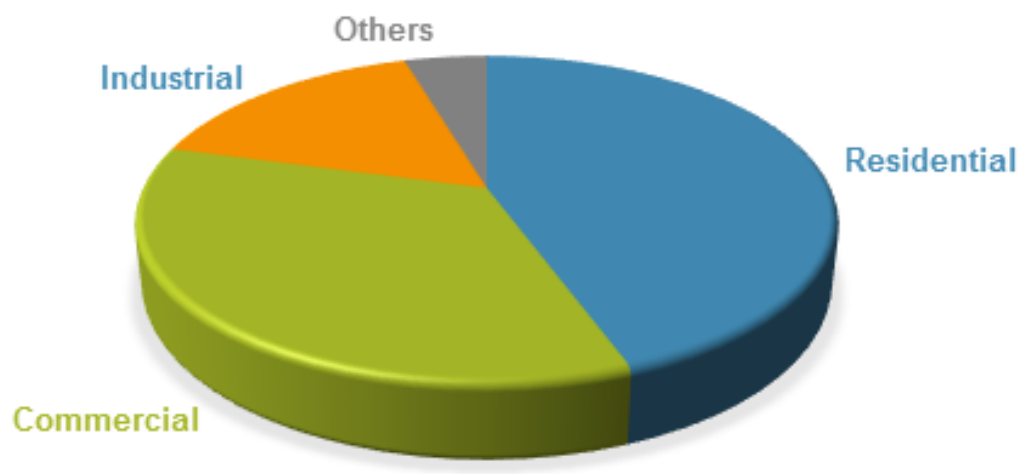




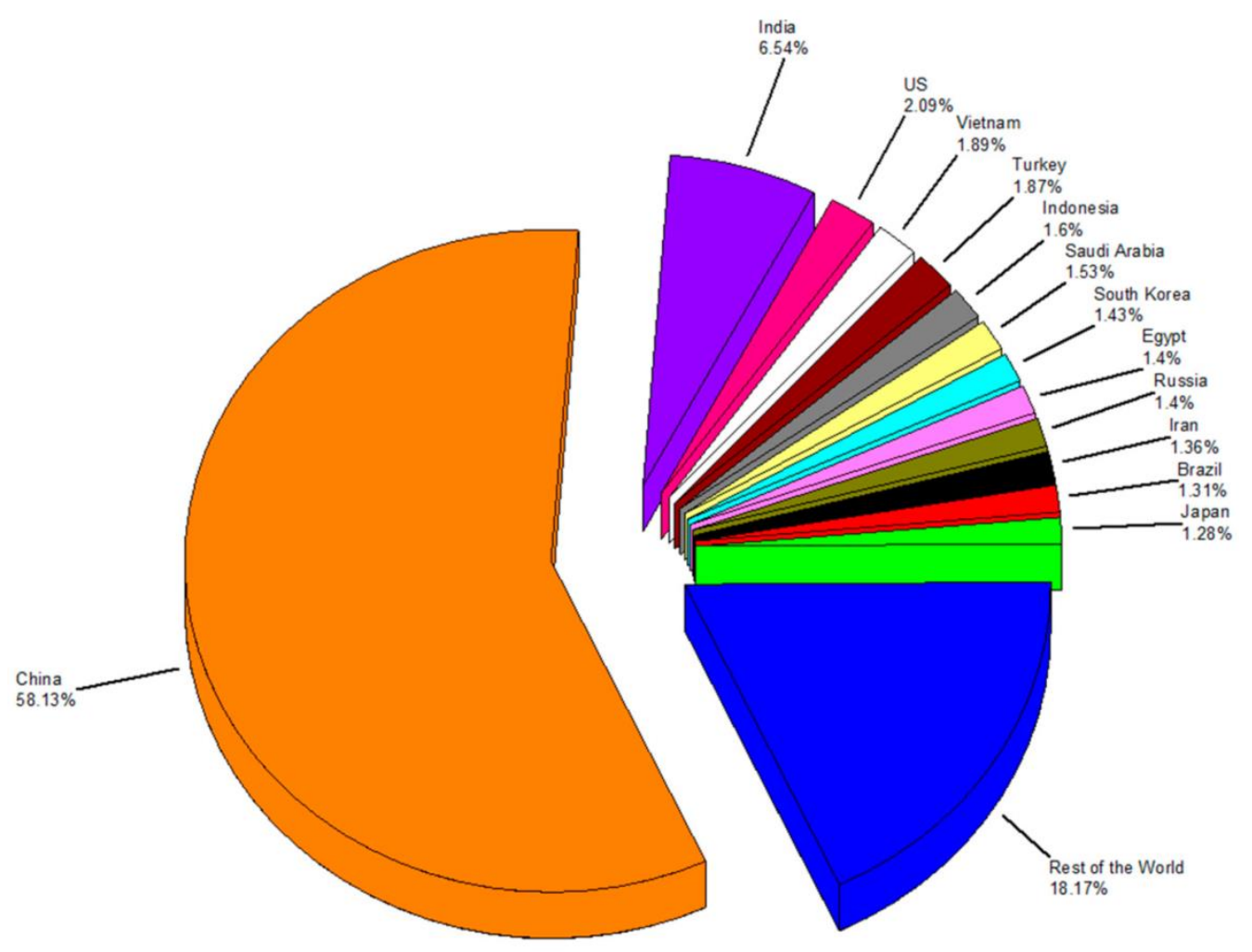

Fig 3. Global cement production

\section{CONCLUSION}

This paper shows that it will not only reduce the emission of $\mathrm{CO} 2$ in environment and environmental impact but it is also cost-effective to produce in future. In this paper we have discussed the various chemical composition of green cement with benefits and limitations.

\section{REFERENCES}

[1]. Swamy RN, Mehmod HB. Mix proportions and strength characteristics of concrete containing 50\% low calcium fly ash. In: Malhotra VM, editor. Proceedings of the second international congress on fly ash, silica fume, slag and national pozzolanas in concretes, Madrid, ACJ SP 91, vol. 1; 1986. p. 41332.

[2]. Orsos, T., 'BST: The Lightweight concrete aggregate', Concrete Institute of Australia seminar on Special Use Concretes, Melbourne, 1992.

[3]. Ahmed E. Ahmed and Ahmed A. E. kourd.1989. Properties of concrete incorporating natural and crushed stone very fine sand.ACI Material journal.86 (4):417-424. 
[4]. Rebeiz, K. S., 1996. Precast use of polymer concrete using unsaturated polyester resin based on recycled PET waste. Construction and Building Materials 10 (3), 215-220.

[5] T. Punmatharith, M. Rachakornkij, A. Imyim, and M.Wecharatana, "Co-processing of grinding sludge as alternative raw material in portland cement clinker production," Journal of Applied Sciences, vol. 10, no. 15, pp. 1525-1535, 2010.

[6] D. N. Huntzinger and T. D. Eatmon, "A life-cycle assessment of Portland cement manufacturing: comparing the traditional process with alternative technologies," Journal of Cleaner Production, vol. 17, no. 7, pp. 668-675, 2009.

[7] K. Ganesan, K. Rajagopal, and K. Thangavel, "Evaluation of bagasse ash as supplementary cementitious material," Cement and Concrete Composites, vol. 29, no. 6, pp. 515-524, 2007.

[8] S. Sinthaworn and P. Nimityongskul, "Quick monitoring of pozzolanic reactivity of waste ashes," Waste Management, vol.29, no. 5, pp. 1526-1531, 2009. 